\title{
Kriteria Keseimbangan Dalam Perjanjian Kredit Bank Untuk Mewujudkan Keadilan Komutatif
}

\author{
Tiar Ramon \\ Fakultas Hukum Universitas Islam Indragiri \\ Jln. Subrantas No. 10 Tembilahan Kabupaten Indragiri Hilir Riau \\ tiarramon17@gmail.com
}

Received: 26 Oktober 2018; Accepted: 26 Juni 2019; Published: 22 Agustus 2019

DOI: 10.20885/iustum.vol26.iss2.art8

\begin{abstract}
Commutative justice is an embodiment of balance in an agreement, including a bank credit agreement as the standard. There needs to be a balance criterion proving the fulfilment of commutative justice. This study aims to determine the threshold of the balance in bank credit agreements to realize commutative justice. This research is a normative legal research, with the agreement norm system approach as the object of the research by using secondary data. The results of the study concluded that there are 3 (three) balance criteria: the absence of dominance, the harmonization of the contents of the agreement, and non-violation of the principle of justice. If these criteria are not sufficed when a lawsuit is filed, it may be used as a basis or reason according to the law, for the court to annul the agreement for violationg the principle balance.
\end{abstract}

Keywords: Balance; credit agreement; commutative justice

\section{Abstrak}

Keadilan komutatif merupakan wujud adanya keseimbangan dalam perjanjian, termasuk perjanjian kredit bank sebagai perjanjian baku. Perlu ada kriteria keseimbangan bahwa telah terwujudnya keadilan komutatif. Penelitian ini bertujuan mengetahui kriteria keseimbangan dalam perjanjian kredit bank untuk mewujudkan keadilan komutatif. Penelitian ini adalah penelitian hukum normatif, dan sistem norma perjanjian sebagai objek penelitiannya. Data yang digunakan adalah data sekunder. Hasil penelitian menyimpulkan kriteria keseimbangan ada 3, yaitu tidak adanya pihak dominasi, adanya harmonisasi isi perjanjian, dan tidak melanggar asas keadilan. Apabila kriteria tersebut tidak terpenuhi ketika suatu saat diajukan gugatan, maka dapat dijadikan dasar atau alasan menurut hukum, sehingga pengadilan dapat membatalkan perjanjian karena melanggar asas hukum yaitu asas keseimbangan.

Kata-kata Kunci: Keseimbangan; perjanjian kredit; keadilan komutatif 


\section{Pendahuluan}

Keadilan merupakan tujuan filosofis hukum sebagai cita-cita tertinggi hukum. Menurut Aristoteles, ada 2 keadilan yaitu keadilan distributif dan keadilan komutatif. Keadilan komutatif atau keadilan kebersamaan (justitia commutativa) inilah yang harus diwujudkan dalam perjanjian, karena keadilan ini tidak memandang derajat dan kedudukan dalam kehidupan masyarakat. ${ }^{1}$ Melalui keadilan komutatif masing-masing pihak akan memeroleh hasil yang diharapkan dari pertukaran pelaksanaan janji-janji yang dibuat dan berlangsung secara fair dan bebas, sehingga terhindar dari upaya "pengayaan diri tanpa hak" (unjust enrichment). ${ }^{2}$

Keadilan komutatif cenderung sulit terwujud dalam suatu perjanjian baku. Perjanjian kredit perbankan misalnya, sebagai perjanjian baku karena perjanjiannya telah disusun terlebih dahulu, bersifat standar dan tidak ada unsur kebebasan untuk memilih sebagai unsur tradisional dalam kebebasan berkontrak, ${ }^{3}$ atau perjanjian yang dibuat hampir seluruh klausul-klausulnya sudah dibakukan oleh pemakainya, sehingga para pihak tidak mempunyai peluang untuk bernegosiasi atau meminta perubahan. ${ }^{4}$ Kepentingan untuk menyeragamkan dan efisiensi perusahaan untuk merumuskan seluruh atau sebagian besar klausul perjanjian secara sepihak menjadi alasan penerapan perjanjian baku ini. ${ }^{5}$

Pada prinsipnya, yang terpenting dari perjanjian kredit bank sebagai perjanjian baku adalah tidak menimbulkan persoalan ketidakadilan atau berat sebelah dalam hal cakupan isi perjanjian (prestasi) yang dibuat, sehingga dapat merugikan bagi salah satu pihak yaitu pada debitur yang lemah. Apabila

${ }^{1}$ Keadilan komutatif adalah suatu keadilan yang memberikan kepada setiap orang sama banyaknya tanpa mengingat jasa masing-masing. Di sini yang dituntut adalah kesamaan, yang adil adalah apabila setiap orang dipelakukan sama tanpa memandang kedudukan dan sebagainya.Lihat Sudikno Mertukusumo, Mengenal Hukum: Suatu Pengantar, Cetakan Kedua, Liberty, Yogyakarta, 2005, hlm. 79. hlm. 121.

2'Tim Penyusun, Naskah Akademik. Hukum Kontrak, BPHN Kementrian Hukum dan HAM RI, Jakarta, 2013,

${ }^{3}$ Verra Bolgar, The Contract of Adhesion a Comparison of Theory and Practice, 20 AJCI. 53, 1972, dalam Sutan Remy Sjahdeini, Kebebasan Berkontrak dan Perlindungan Yang Seimbang Bagi Para Pihak Dalam Perjanjian Kredit Bank Di Indonesia, Institut Bankir Indonesia, Jakarta, 1993, hlm. 10.

${ }^{4}$ Ibid., hlm. 66.

${ }^{5}$ R.M. Panggabean, "Keabsahan Perjanjian Baku dengan Klausul Baku”, Jurnal Hukum, No. 4 Vol. 1 Oktober 2010, hlm. 52. 
menimbulkan ketidakadilan dan berat sebelah tentunya tidak terwujud keadilan komutatif sebagai tujuan keadilan dalam bidang hukum perjanjian.

Hal di atas dapat saja terjadi karena dalam praktik sebelum penandatanganan perjanjian, pihak bank sebagai kreditur yang berkedudukan kuat secara ekonomis, secara sepihak telah mempersiapkan isi atau klausul-klausul perjanjian dalam suatu formulir tercetak. ${ }^{6}$ Situasi ini yang disebut dengan kedudukan yang tidak seimbang, ${ }^{7}$ maka perlu keseimbangan dalam perjanjian, baik keseimbangan posisi maupun ekonomi agar keadilan komutatif atau kebersamaan dapat terwujud.

Keseimbangan harus terwujud dengan tidak ada satu pun pihak yang mendominasi, atau karena tidak ada satu pun elemen yang menguasai lainnya". 8 Apabila dalam perjanjian kredit elemen tersebut adalah para pihak, baik pihak kreditur maupun pihak debitur, maka tidak boleh saling menguasai atau mendominasi yang lainnya, baik karena alasan derajat atau status ekonomi.

Praktiknya, perjanjian kredit bank justru ada yang menimbulkan ketidakadilan atau berat sebelah karena kedudukan para pihak yang tidak seimbang, yaitu kedudukan bank selaku kreditur lebih kuat daripada debitur. Situasi ini menimbulkan cakupan prestasi yang tidak adil. Sebagai contoh yang dapat penulis kemukakan, bahwa persoalan ini pernah terjadi dalam Perjanjian Kredit Modal Kerja pada PT. Bank Riau Cabang Tembilahan yang debiturnya adalah pedagang makanan dan minuman.

Adapun klausul yang menimbulkan ketidakseimbangan dapat dilihat dari adanya larangan kepada debitur mengikatkan diri sebagai penjamin (borg) dan menjaminkan harta kekayaanya. Padahal, dalam perjanjian tersebut debitur telah menyerahkan jaminan berupa agunan yaitu sebidang tanah. Lebih lengkapnya

${ }^{6}$ Ibid., hlm. 182.

${ }^{7}$ Ahmadi Miru dan Sutarman Yodo berpendapat apabila dalam suatu perjanjian, kedudukan para pihak tidak seimbang, maka pihak lemah biasanya tidak berada dalam keadaan yang betul-betul bebas untuk menentukan yang diinginkan dalam perjanjian. Dalam hal demikian pihak yang memiliki posisi kuat biasanya menggunakan kesempatan tersebut untuk menentukan klausula-klausula tertentu dalam perjanjian baku, sehingga perjanjian yang seharusnya dibuat atau dirancang oleh para pihak yang terlibat dalam perjanjian, tidak ditemukan lagi dalam perjanjian baku, karena format dan isi perjanjian dirancang oleh pihak yang kedudukannya lebih kuat.Lihat Ahmadi Miru dan Sutarman Yodo, Hukum Perlindungan Konsumen, Raja Grafindo Persada, Jakarta, 2007, hlm. 114.

${ }^{8}$ Van Dale, Groot Woordenboek der Nederlandse Taal, Tiende drunk, Utrecht/Antwerpen, 1982, hlm. 651, dalam Herlien Budiono, Asas Keseimbangan Bagi Hukum Perjanjian Indonesia : Hukum Perjanjian Berdasarkan Asas-Asas Wigati Indonesia, Citra Aditya Bakti, Bandung, 2006, hlm. 304. 
larangan tersebut tercantum dalam Pasal 12 Surat Perjanjian Kredit, yang berbunyi: ${ }^{9}$

"Selama jangka waktu kredit dan sampai kredit dilunasi, debitur dilarang melakukan tindakan yang dapat merugikan bank sebagaimana yang telah disebutkan dalam Pasal 1 huruf c perjanjian kredit ini, kecuali dalam hal terlebih dahulu telah mendapat persetujuan bank".

Adapun bunyi Pasal 1 huruf c angka 11 yaitu:

Tindakan yang dapat merugikan bank adalah tindakan, perbuatan atau kebijakan Debitur yang mempunyai akibat berupa kemungkinan terjadinya kerugian Bank atau terganggunya kepentingan Bank dalam memperoleh pembayaran pelunasan kredit oleh Debitur yaitu berupa mengikatkan diri sebagai penjamin (borg), menjaminkan harta kekayaan dalam bentuk dan maksud apapun kepada pihak lain.

Klausul yang tidak adil sebagaimana dicontohkan di atas merupakan permasalahan hukum apabila ditelaah lebih mendalam dari perspektif keadilan komutatif. Hal tersebut dikarenakan adanya ketidakseimbangan prestasi akibat dari ketidakseimbangan kedudukan para pihak. Penulis tidak secara khusus memberikan analisis terhadap klausul yang tidak adil tersebut, hal di atas sebatas sebagai contoh atau ilustrasi nyata mengenai klausul yang tidak adil dalam perjanjian kredit bank.

Permasalahan yang kemudian menarik untuk diteliti adalah mengenai kriteria keseimbangan yang dapat di internalisasikan dalam perjanjian kredit bank sehingga dapat mewujudkan keadilan komutatif. Melalui adanya kriteria keseimbangan tersebut semestinya dapat dijadikan sebagai landasan bagi penyusunan perjanjian kredit bank. Apabila kriteria tersebut dilanggar atau tidak terpenuhi, maka dapat dijadikan dasar atau alasan menurut hukum bahwa pengadilan dapat membatalkan suatu perjanjian karena melanggar asas keseimbangan yang dalam perkembangan hukum perjanjian telah dijadikan sebagai asas keseimbangan. ${ }^{10}$

\footnotetext{
${ }^{9}$ Surat Perjanjian Kredit Modal Kerja PT. Bank Riau Cabang Tembilahan Nomor 9070.1.06.2006.03.

${ }^{10}$ Asas keseimbangan pertama kali dikenalkan pada Lokakarya Hukum Perikatan oleh Badan Pembinaan Hukum Nasional Deparetmen Kehakiman RI, di Jakarta pada tanggal 17 - 19 Desember Tahun 1985. Lihat Tim Naskah Akademis BPHN, Naskah Akademis Lokakarya Hukum Perikatan, Badan Pembinaan Hukum Nasional, Jakarta, 1985.
} 


\section{Rumusan Masalah}

Berdasarkan latar belakang di atas, maka permasalahan penelitian ini yaitu bagaimana kriteria keseimbangan dalam perjanjian kredit bank untuk mewujudkan keadilan komutatif?

\section{Tujuan Penelitian}

Adapun tujuan penelitian dalam penulisan ini adalah untuk mengetahui kriteria keseimbangan dalam perjanjian kredit bank untuk mewujudkan keadilan komutatif.

\section{Metode Penelitian}

Penelitian ini menggunakan metode penelitian hukum normatif atau penelitian kepustakaan (library research). ${ }^{11}$ Penelitian hukum normatif adalah penelitian hukum yang meletakkan hukum sebagai sebuah bangunan sistem norma. Sistem norma yang dimaksud adalah mengenai asas-asas, norma dari peraturan perundang-undangan, putusan pengadilan, produk hukum, perjanjian serta doktrin. ${ }^{12}$ Penelitian ini mendudukkan sistem norma perjanjian sebagai objek penelitiannya. Data yang digunakan adalah data sekunder yang bersumber dari bahan hukum primer, bahan hukum sekunder dan bahan hukum tersier. Data yang diperoleh kemudian dianalisis secara kualitatif.

\section{Hasil Penelitian dan Pembahasan}

Menurut Kamus Ilmiah Populer, "kriteria" diartikan sebagai syarat utama, ukuran (patokan) baku untuk menentukan sesuatu,13 sedangkan "keseimbangan" sebagaimana diuraikan sebelumnya menunjuk pada pengertian keadaan pembagian beban kedua sisi berada dalam keadaan seimbang. "Keseimbangan" dalam penelitian ini dipahami sebagai "keadaan hening atau keselarasan karena dari pelbagai gaya yang bekerja tidak satu pun mendominasi yang lainnya, atau karena tidak ada elemen menguasai lainnya". Keadaan pembagian beban dalam konteks perjanjian tentunya tidak boleh ada yang mendominasi, terutama jika

$$
11 .
$$

${ }^{11}$ Ronny Hanitijo Soemitro, Metodologi Penelitian Hukum dan Jurimetri, Ghalia Indonesia, Jakarta, 1990, hlm.

${ }^{12}$ Mukti Fajar \& Yulianto Achmad, Dualisme Penelitian Hukum Normatif \& Empiris, Pustaka Pelajar, Yogyakarta, 2010, hlm. 34.

${ }^{13}$ M. Ridwan, dkk, Kamus Ilmiah Populer, Pustaka Indonesia, Jakarta, 2006, hlm. 309-310. 
dominasi tersebut menimbulkan ketidakadilan dan kerugian pada salah satu pihak, sehingga membuat salah satu pihak tidak sanggup melaksanakan isi perjanjian (prestasi).

Penulis menilai perlu adanya kriteria keseimbangan untuk mewujudkan keadilan komutatif (keadilan para pihak) dalam sebuah perjanjian kredit bank. Apabila kriteria tersebut tidak terpenuhi, maka menurut hukum, perjanjian kredit menjadi tidak seimbang, sehingga melanggar asas keseimbangan. Berdasarkan asas keseimbangan, kriteria tersebut dapat dijadikan sebagai dasar atau pedoman keabsahan berlakunya perjanjian, termasuk dalam perjanjian kredit bank. Penentuan kriteria ini menjadi penting, apabila suatu saat terjadi indikasi ketidaksetaraan antara para pihak dalam suatu perjanjian, maka kriteria ini dapat digunakan sebagai alat ukur untuk menentukan kesimpulan dari indikasi tersebut. Asas keseimbangan sebagai asas yang saat ini berkembang sudah seharusnya patut diperhatikan selain asas kesepakatan (consensus), asas kekuatan mengikatnya (pact sunt servanda) dan asas kebebasan berkontrak (freedom of contract).

"Kriterium keseimbangan itu tidak boleh dicari apakah situasi atau sasaran yang hendak dicapai itu tidak seimbang, seperti pada perjanjian penghibahan. Akan tetapi lebih dalam pertanyaan, apakah pada saat terjadinya perjanjian terdapat masalah ketidakseimbangan dalam cara pembuatan kontrak dan apakah perjanjian yang bersangkutan mengandung muatan atau maksud dilakukannya perjanjian dan pelaksanaan prestasi yang dapat membawa kontrak itu pada suatu keadaan yang tidak seimbang. ${ }^{14}$

Merujuk pendapat Herlien Budiono di atas, kriteria keseimbangan perjanjian ditekankan untuk mencermati proses pembuatan dan muatan perjanjian. Terlepas dari situasi atau sasaran yang hendak dicapai dalam suatu perjanjian dapat menimbulkan keseimbangan atau tidak, namun pencermatan terhadap pewujudan asas keseimbangan dalam suatu perjanjian memerlukan alat ukur berupa kriteria keseimbangan sebagaimana yang akan dibahas dalam penelitian ini.

Ketidakseimbangan hanya berpotensi terjadi pada perjanjian timbal balik atau dua pihak, bukan pada perjanjian sepihak sebagaimana dalam perjanjian hibah. Perjanjian timbal balik atau dua pihak adalah perjanjian yang memunculkan

${ }^{14}$ Herlien Budiono, Op. Cit., hlm. 543. 
hak dan kewajiban kepada masing-masing pihak. Sedangkan perjanjian hibah sebagai perjanjian sepihak adalah perjanjian atas adanya kesepakatan pemberian sukarela dan yang menerima juga harus sukarela tanpa paksaan, serta tekanan dari pihak manapun. ${ }^{15}$

Asas keseimbangan perlu diimplementasikan dalam penyusunan perjanjian agar dapat mewujudkan keadilan bagi para pihak (keadilan komutatif) dengan mengacu pada kriteria-kriteria tertentu. Tujuan asas keseimbangan adalah mewujudkan keadilan bagi kedua belah pihak karena keseimbangan mengandung makna keselarasan dan tidak ada unsur atau elemen yang saling menguasai, terutama penguasaan pihak yang kuat terhadap yang lemah. Asas keseimbangan harus dijadikan dasar untuk menentukan keabsahan suatu perjanjian, sehingga apabila suatu saat ada perjanjian yang melanggar asas keseimbangan dan hal tersebut dapat dibuktikan, maka pengadilan dapat membatalkan perjanjian tersebut.

Uraian di atas menunjukkan betapa pentingnya asas keseimbangan dalam suatu perjanjian. Mengingat asas keseimbangan merupakan suatu asas untuk mewujudkan keadilan komutatif bagi para pihak, maka perjanjian kredit bank harus dibentuk dengan mengacu pada kriteria keseimbangan yang dapat merujuk analisis gagasan penulis sebagai berikut:

\section{Tidak Ada Pihak yang Mendominasi}

Dominasi adalah penguasaan, penempatan posisi bagus dan kuat, serta pengaruh besar. ${ }^{16}$ Pada konteks perjanjian, khususnya dalam perjanjian timbal balik, posisi dominasi ini berkaitan dengan kesetaraan pihak-pihak atau kesederajatan. ${ }^{17}$ Ketidaksetaraan terjadi karena adanya salah satu pihak yang kedudukannya secara ekonomi lebih kuat, misalnya dalam perjanjian kredit bank antara Bank selaku kreditur dengan pedagang Usaha Kredit Mikro selaku debitur, maka kedudukan Bank cenderung lebih kuat daripada pedagang Usaha Kredit Mikro.

${ }^{15}$ Lihat Pasal 1320 Kitab Undang-Undang Hukum Perdata

${ }^{16}$ M. Ridwan, dkk, Op. Cit., hlm. 97-98.

${ }^{17}$ Ricardo Simanjuntak, Teknik Perancangan Kontrak Bisnis, Kontan Publishing, Jakarta, 2011, hlm. 183. 
Perjanjian kredit bank merupakan perjanjian baku yang isinya telah ditentukan secara sepihak oleh pihak bank, dengan tujuan efisiensi. Pada satu sisi, pelaku usaha kecil tentu sangat memerlukan dana untuk mengembangkan usahanya. Situasi tersebut "memaksa" pelaku usaha untuk menyetujui ketentuanketentuan perjanjian kredit, meski sebenarnya prestasi yang harus ditunaikan oleh debitur (pelaku usaha) relatif memberatkan. ${ }^{18}$ Apabila kondisi ini terjadi, tentunya menimbulkan ketidakadilan. Padahal, Pancasila sebagai falsafah Negara Indonesia menganut asas keselarasan dan kesetaraan, baik dalam hidup manusia sebagai pribadi dan dalam hubungan manusia dengan masyarakat. ${ }^{19}$ Pancasila sebagai nilai-nilai luhur seharusnya dijadikan sebagai pedoman dalam setiap aktivitas kehidupan.

Ketidakseimbangan kedudukan antara para pihak dalam suatu perjanjian, sering menyebabkan pihak yang kedudukannya lebih rendah atau lemah akan mengalami keadaan yang kurang menguntungkan. Ketidakseimbangan dalam perjanjian dapat dimanfaatkan oleh pihak yang dominan, sehingga memicu penyalahgunaan keadaan. Misalnya, dalam perjanjian kredit memuat klausula eksonerasi/eksemsi berupa penambahan hak dan/atau pengurangan kewajiban bank, atau mengurangi hak dan/atau menambah kewajiban nasabah debitur. ${ }^{20}$

Kedudukan kuat secara ekonomi memang tidak menjadi persoalan, namun yang perlu menjadi perhatian adalah pengaruh kedudukan kuat secara ekonomi tersebut terhadap cakupan perjanjian. Sejauh mana kedudukan kuat tersebut berdampak pada dominasi pihak bank untuk mengatur isi perjanjian, sehingga pihak yang lemah (debitur) tidak memiliki pilihan lain selain menyetujui perjanjian, karena dalam keadaan membutuhkan kredit. Bahkan dalam situasi ini debitur tidak memiliki posisi tawar (bergaining position). Jika hal ini terjadi, maka akan melahirkan perjanjian yang berat sebelah dan tidak adil.

Kesetaraan kedudukan dan hak para pihak merupakan suatu hal yang tidak dapat dipisahkan, sehingga para pihak tidak boleh ada yang mendominasi dalam

\footnotetext{
${ }^{18}$ Etty Mulyati, Asas Keseimbangan Pada Perjanjian Kredit Perbankan Dengan Nasabah Pelaku Usaha Kecil, Jurnal Bina Mulia Hukum, Vol. 1, No. 1, September 2016, hlm. 36.

${ }^{19}$ Arvie Johan, "Kesetaraan Dan Keseimbangan Sebagai Perwujudan Itikad Baik Berlandaskan Pancasila", artikel dalam Jurnal Ilmu Hukum, Vol. 14, No. 1, Vol. 14 Maret 2011, hlm. 130.

${ }^{20}$ Etty Mulyati, Op. Cit., hlm. 38.
} 
menentukan isi perjanjian (bargaining position). John Rawls menyebut dengan istilah kesetaraan kedudukan dan hak, bukan dalam arti kesamaan hasil yang dapat diperoleh setiap orang, melainkan suatu keadaan bahwa setiap orang setara/seimbang dalam hukum (perjanjian). ${ }^{21}$ Ketidaksetaraan kedudukan dan prestasi dalam perjanjian baku (standart contract) kredit bank antara pihak bank (kreditur) dengan pihak nasabah (debitur) ini seharusnya dapat diajukan tuntutan pembatalan perjanjian dengan alasan ketidakabsahan perjanjian sebagai akibat dari ketidaksetaraan. Sebagaimana pendapat Herlien Budiono yang mengatakan akibat hukum atas ketidaksetaraan prestasi dalam perjanjian timbal balik.

"Jika kedudukan lebih kuat tersebut berpengaruh terhadap perhubungan prestasi satu dengan yang lainnya, dan hal mana mengacaukan keseimbangan dalam perjanjian, hal ini bagi pihak yang dirugikan akan merupakan alasan untuk mengajukan tuntutan ketidakabsahan perjanjian. Sepanjang prestasi yang dijanjikan bertimbal balik mengandaikan kesetaraan, maka bila terjadi ketidakseimbangan, perhatian akan diberikan terhadap kesetaraan yang terkait pada bagaimana perjanjian terbentuk, dan tidak pada hasil akhir dari prestasi yang ditawarkan secara bertimbal balik." 22

Pernyataan di atas semakin menerangkan bahwa ketidakseimbangan terjadi karena timbulnya kedudukan yang tidak setara karena ada pihak yang mendominasi suatu perjanjian. Posisi dominan tersebut tentu akan memengaruhi prestasi-prestasi timbal balik yang dibuat atau hak dan kewajiban yang dibebankan pada masing-masing pihak.

Doktrin pengaruh tidak pantas atau tidak seimbang (undue influence) mengajarkan bahwa suatu kontrak batal atau dapat dibatalkan dengan alasan tidak tercapainya kesesuaian kehendak yang disebabkan adanya usaha salah satu pihak yang berkedudukan lebih dominan. Usaha tersebut biasanya dilakukan dengan cara-cara persuasif dalam rangka mengambil keuntungan yang tidak fair dari pihak lain. Kontrak baku dapat saja berisi hal-hal yang merupakan pengaruh tidak pantas, hubungan yang tidak wajar antara kedua belah pihak, dan klausul-klausul yang dapat merugikan pihak lain dalam suatu perjanjian. Undue Influence adalah bujukan, tekanan, atau pengaruh tanpa kekuatan fisik atau nyata yang lebih dari

${ }^{21}$ Agus Yudha Hernoko, Hukum Perjanjian : Asas Proporsionalitas Dalam Kontrak Komersial, Kencana, Jakarta, 2010, hlm. 58 .

${ }^{22}$ J.H. Nieuwehuis, Drie Beginselen van Contractenrecht, Disertasi, Rul 1979, Deventer, Leiden, 1979, hlm. 122, dalam Disertasi Herlien Budiono, Op. Cit., hlm. 318-319. 
nasihat biasa. Undue Influence dapat memengaruhi pendapat atau kemauan dari pihak yang dikuasai sehingga tidak dapat bertindak secara bebas dan cermat, tetapi bertindak sesuai dengan kemauan atau maksud dari pihak yang memengaruhinya. ${ }^{23}$ Dominasi salah satu pihak dalam sebuah perjanjian dapat bersifat psikologi maupun ekonomi.

Pengadilan di Indonesia menerapkan doktrin pengaruh tidak seimbang atau tidak pantas (undue influence) ini. Sebagai contoh, dalam kasus Made Oka Masagung v. PT. Bank Artha Graha, Notaris Koesbiono Sarmanhadi SH, Sugianto Kusuma dan PT. Binajaya Padukreasi, No. 3641 K/Pdt/2001, Mahkamah Agung (MA) mempertimbangkan bahwa salah satu syarat bagi keabsahan suatu kontrak adalah bahwa kata sepakat harus diberikan atas dasar kehendak bebas. Made Oka Masagung menandatangani akta jual beli, untuk memindahkan alas hak atas harta kekayaannya sewaktu dia di penjara. Penandatanganan akta tersebut disertai dengan janji Bank Artha Graha untuk mengupayakannya bebas dari penjara. Kondisi tersebut memengaruhi tindakan Made Oka Masagung untuk mengalihkan harta kekayaan yang dimiliki. MA menyatakan bahwa perilaku Bank Artha Graha merupakan penyalahgunaan keadaan (misbruik van de omstandigheden), karena itu perjanjian dan akta jual beli dinyatakan tidak sah dan dibatalkan. ${ }^{24}$

\section{Adanya Harmonisasi Isi Perjanjian (Prestasi)}

Harmonisasi adalah upaya pengharmonisan, penyelarasan, penyerasian. ${ }^{25}$ Harmonisasi isi perjanjian mengandung maksud bahwa hak dan kewajiban para pihak sesuai (selaras) dengan beban pelaksanaannya. Perjanjian harus mencerminkan kepentingan bersama sebagai wujud bahwa asas kesepakatan telah diterapkan dalam perjanjian tersebut. Tidak ada hak salah satu pihak bertentangan dengan hak pihak lainnya dan tidak ada kewajiban salah satu pihak bertentangan dengan kewajiban pihak lainnya. Semua harus didasarkan atas kehendak bersama sebagaimana makna yang terkandung dalam asas kesepakatan (persesuaian kehendak). Hal inilah yang penulis maksud dengan harmonisasi isi perjanjian.

\footnotetext{
${ }^{23}$ Rosa Agustina, Hukum Perikatan(Law Of Obligations), Pustaka Larasan, Bali, 2012 hlm. 92.

${ }^{24}$ Ahmad Fikri Assegaf, Penjelasan Klausula Baku, PSHK, Jakarta, 2014, hlm. 81-82.

25 M. Ridwan, dkk, Op. Cit., hlm. 171.
} 
Ketidakharmonisasian isi perjanjian mengindikasikan ketidakseimbangan beban yang harus ditanggung salah satu pihak. Hal ini dapat dilihat dari kewajiban yang banyak dibebankan kepada salah satu pihak saja, sementara hak-haknya dikurangi atau dibatasi. Ketidakhamonisan dalam isi perjanjian kredit bank berpotensi selalu terjadi. Hal ini disebabkan oleh pengaruh dari pihak yang kedudukannya mendominasi salah satu pihak, sementara pihak yang "lemah" hanya mengikuti atau menyetujui isi perjanjian karena terdorong kebutuhan.

Harmonisasi isi perjanjian (prestasi) menjadi penting, agar hak dan kewajiban yang termuat dalam perjanjian tersebut benar-benar mencerminkan kepentingan para pihak. Apabila kriteria ini terpenuhi, maka dipastikan dapat mewujudkan keadilan bagi kedua belah pihak. Bukan justru sebaliknya hanya menguntungkan salah satu pihak yang mendominasi tanpa hak (unjust enrichment).

\section{Tidak Melanggar Asas Keadilan.}

Asas hukum mengandung nilai yang mencerminkan kaidah hukum tertinggi dari suatu sistem hukum positif. ${ }^{26}$ Keadilan merupakan diskursus fundamental dalam hukum. Kaum Naturalis mengatakan bahwa tujuan utama hukum adalah keadilan. ${ }^{27}$ Hal ini sejalan dengan teori tujuan hukum yaitu teori etis yang mengajarkan hukum itu semata-semata menghendaki keadilan. ${ }^{28}$ Agar peraturanperaturan hukum dapat berlaku dan diterima oleh seluruh anggota masyarakat, maka peraturan-peraturan hukum harus sesuai dan tidak boleh bertentangan dengan asas keadilan. ${ }^{29}$

Menurut Aristoteles, keadilan adalah unicuique suum tribuere (memberikan kepada setiap orang sesuatu yang menjadi haknya) dan neminem laedere (janganlah merugikan orang lain), atau lengkapnya menurut Kant adalah honeste vivere, neminem laedere, suum quique tribuere/tibuendi. ${ }^{30}$ Jika seseorang tidak memberikan sesuatu yang menjadi hak orang lain dan melakukan perbuatan yang merugikan

${ }^{26}$ J.J.H. Bruggink alih bahasa B. Arief Sidharta, Rechts Reflecties (Refleksi Tentang Hukum), Citra Aditya Bankti, Bandung, 1999, hlm. 132.

${ }^{27}$ Dominikus Rato, Filsafat Hukum : Mencari, Menemukan, dan Memahami Hukum, LaksBang Justitia, Surabaya, 2010, hlm. 54 .

${ }^{28}$ Sudarsono, Pengantar Ilmu Hukum, Rineka Cipta, Jakarta, 2007, hlm. 52.

${ }^{29}$ C.S.T. Kansil dan Christine S.T. Kansil, Pengantar Ilmu Hukum Indonesia, Rineka Cipta, Jakarta, 2011, hlm. 36.

\footnotetext{
30Dominikus Rato, Op. Cit., hlm. 55.
} 
orang lain, maka dapat dipastikan seseorang tersebut telah berlaku tidak adil. Negara harus menjamin keadilan dapat terwujud dalam kehidupan sehari-hari karena keadilan merupakan hak asasi setiap manusia. Keadilan akan dirasakan masyarakat apabila hak-haknya telah terpenuhi sebagaimana mestinya.

Mewujudkan keadilan merupakan bentuk perlindungan terhadap hak asasi manusia, baik individu maupun kelompok untuk menuju masyarakat yang aman, tenteram dan sejahtera. Hal ini dapat dilakukan dengan cara menyeimbangkan hak dan kewajiban para pihak dalam suatu perjanjian, misalnya dalam perjanjian timbal balik kredit bank. Pewujudan asas keadilan dalam berkontrak yang dibuat oleh para pihak harus disertai dengan asas keseimbangan. ${ }^{31}$ Perjanjian antara para pihak pada hakikatnya tidak dapat dipisahkan dari masalah keadilan, karena dalam perjanjian harus ada pertukaran hak dan kewajiban secara adil.

Hukum perjanjian lahir dari pemikiran untuk memberi keadilan bagi para pihak. Asas keseimbangan dalam perjanjian merupakan unsur penting dalam mewujudkan keadilan, sekaligus sebagai upaya untuk menegakkan hukum dalam bidang perjanjian. ${ }^{32}$ Tercapainya keadilan adalah filosofi dari tujuan hukum karena keadilan merupakan tujuan substantif dari hukum. Hukum terasa "hambar" jika keadilan tidak terwujud dalam setiap peristiwa hukum, termasuk dalam peristiwa hukum perjanjian. Walaupun keadilan bukanlah satu-satunya tujuan hukum, diantara kepastian dan kemanfaatan hukum, namun tujuan hukum yang paling substantif adalah keadilan. Sebuah adagium hukum Summum ius, summa injuria, summa lex, summa crux (hukum yang keras dapat melukai, kecuali keadilan yang dapat menolongnya). ${ }^{33}$

Jika pokok persoalan dalam hukum adalah manusia, maka pokok persoalan bagi manusia yang hendak dicapainya melalui hukum adalah keadilan. ${ }^{34}$ Berdasarkan pertimbangan ini, berkembang gagasan bahwa asas keseimbangan

\footnotetext{
${ }^{31}$ Jonneri Bukit, Made Warka dan Krisnadi Nasution, Eksistensi Asas Keseimbangan Pada Kontrak Konsumen Di Indonesia, Jurnal Ilmu Hukum, Vol. 14, No. 28 Agustus 2018, hlm. 28.

${ }^{32}$ Niru Anita Sinaga dan Tiberius Zaluchu, Peranan Asas Keseimbangan Dalam Mewujudkan Tujuan Perjanjian, Jurnal Imiah Hukum Dirgantara-Fakultas Hukum Universitas Dirgantara Marsekal Suryadarma, Vol. 8 No.1, September 2017, hlm. 43.

${ }^{33}$ Achmad Ali, Menguak Teori Hukum (Legal Theory) dan Teori Peradilan (Judicialprudence) Termasuk Interpretasi Undang-Undang (Legisprudence), Cetakan kedua, Kencana Prenada Media, 2009, hlm. 217.

34Budiono Kusumohamidjojo, Panduan Untuk. Merancang Kontrak, Grasindo, Jakarta, 2001, hlm. 142.
} 
dapat dipahami sebagai asas yang layak dan adil dan selanjutnya diterima sebagai landasan yuridikal di dalam hukum kontrak Indonesia. ${ }^{35}$ Apabila asas keseimbangan menjadi prinsip hukum perjanjian yang fundamental, maka pelanggaran terhadap asas keseimbangan yang menimbulkan kerugian materi bagi salah satu pihak, semestinya dapat menjadi alasan pembatalan perjanjian ke pengadilan.

Hukum perjanjian pada dasarnya bertujuan untuk mewujudkan keadilan komutatif, sehingga masing-masing pihak akan memeroleh hasil melalui pertukaran pelaksanaan prestasi secara fair dan bebas. Selain itu, harus diakui pula bahwa beberapa situasi khusus di dalam hukum perjanjian juga bertujuan mewujudkan keadilan restoratif (restorative justice). Keadilan restoratif ditujukan untuk memulihkan kedudukan para pihak pada kondisi sebelum perjanjian terbentuk (restitusi), serta upaya untuk mencegah timbulnya situasi yang dapat "memperkaya" salah satu pihak tanpa hak" (unjust enrichment). 36

Kontrak yang berat sebelah (baik dalam bentuk baku ataupun tidak) akan sangat merugikan salah satu pihak, dan oleh karenanya akan sangat menyentuh rasa keadilan masyarakat. Kontrak maupun klausula yang demikian ini tentunya harus dinyatakan batal. ${ }^{37}$ Perjanjian baku yang dibuat oleh bank selain tidak boleh bertentangan dengan undang-undang, juga harus menjunjung tinggi rasa keadilan dan keseimbangan antara para pihak. ${ }^{38}$

Menurut John Rawl, suatu konsep keadilan yang baik harus bersifat kontraktual, konsekuensinya setiap konsep keadilan yang tidak berbasis kontraktual harus dikesampingkan demi kepentingan keadilan itu sendiri. ${ }^{39}$ Pendapat John Rawl ini mengindikasikan bahwa melalui kontrak yang merupakan hasil kesepakatan bersama dapat mewujudkan keadilan. Hal ini disebut dengan teori keadilan berbasis kontrak yang mengutamakan kepentingan bersama.

${ }^{35}$ Herlien Budiono, Op. Cit., hlm. 307.

${ }^{36}$ Ibid., hlm. 73.

${ }^{37}$ Ahmad Fikri Assegaf, Op. Cit., hlm. 81.

${ }^{38}$ Lina Jamilah, Kajian Hukum Atas Perjanjian Kredit dengan Jaminan Pihak Ketiga (Orang) di Indonesia, dalam Neni Sri Ismaniyati, ed, hlm. 122.

${ }^{39}$ Andre Ata Ujan, Keadilan dan Demokrasi (Telaab Filsafat Politik John Rawl, Yogyakarta, Kanisius, 1999, hlm. 21 dan 32 dalam Agus Yudha Hernoko, Ibid., hlm. 55-56. 
Keadilan terwujud dalam suatu perjanjian apabila para pihak mengampu hak dan kewajibannya secara fair dan bebas atau tanpa tekanan. Apabila terjadi ketidakseimbangan posisi diantara para pihak, maka negara harus mengintervensi sebagai upaya pemulihan perjanjian. Hal ini dapat dilakukan melalui putusan pengadilan atau menentukan regulasi yang menentukan batas-batas implementasi asas kebebasan berkontrak dengan memerhatikan asas keseimbangan dan keadilan. ${ }^{40}$ Asas keadilan berkaitan erat dengan pewujudan keadilan komutatif sebagaimana sila ke-5 Pancasila, ${ }^{41}$ maka asas ini harus menjadi asas hukum perjanjian yang fundamental.

Klausul jaminan kredit pada PT Bank Riau Cabang Tembilahan menentukan bahwa Bank melarang debitur sebagai penjamin (borg), serta melarang debitur menjaminkan harta kekayaannya. ${ }^{42}$ Klausul ini mencerminkan sikap Bank yang tidak adil dalam mengatur isi perjanjian kredit tersebut, karena penggunaan hakhak debitur terhadap harta kekayaannya terbatasi. Padahal dalam perjanjian kredit tersebut telah diserahkan harta kekayaan debitur sebagai agunan kredit pelunasan pada Bank yang diikat dalam lembaga jaminan.

Larangan ini tentu menimbulkan ketidakadilan bagi debitur, bahkan merugikan apabila ditinjau dari sisi kepentingan hukum debitur untuk menggunakan hak-hak privatnya. Padahal apabila hak privat debitur tersebut digunakan tentunya tidak akan merugikan kreditur, kecuali dalam perjanjian kredit tersebut tidak ada agunan yang diserahkan kepada kreditur. Ketiadaan agunan debitur dalam perjanjian kredit tentu menjadikan larangan tersebut relevan dalam rangka menjamin pelunasan kredit debitur. Hal ini sebagaimana ketentuan dalam Pasal 1131 KUH Perdata “Segala kebendaan si berutang, baik yang bergerak maupun tidak bergerak, baik yang sudah ada maupun yang akan ada dikemudian hari menjadi tanggungan jaminan untuk segala perikatan perseorangan".

40 Lihat Putusan Mahkamah Agung RI No. 3956 K/Pdt/2000 jo Putusan Pengadilan Tinggi Sby No. 628/Pdt/1999/PT.SBY jo Putusan Pengadilan Negeri GS No. 37/Pdt.G/1998/PN. GS., bahwa pokok putusan ini adalah majelis hakim memutuskan mengembalikan suku bunga pada posisi $21 \%$ dengan pertimbangan perlindungan hukum harus diberikan dalam proporsinya dalam keseimbangan.

${ }^{41}$ Dominikus Rato, Op. Cit., hlm. 64.

42 Pasal 1 huruf c angka 11 dan Pasal 12 Perjanjian Kredit Modal Kerja PT. Bank Riau Cabang Tembilahan Nomor 9070.1.06.2006.03. 
Pasal 1 huruf c angka 11 jo. Pasal 12 Perjanjian Kredit Modal Kerja menentukan kewajiban debitur untuk mengajukan permohonan persetujuan kepada kreditur apabila hendak menjaminkan harta kekayaannya kepada kreditur lain. Kewajiban ini tentu tidak adil, dikarenakan, apabila debitur hendak menjaminkan harta kekayaannya selain yang telah diikatkan pada lembaga jaminan kepada kreditur lainnya,43 sementara kreditur tidak memberi persetujuan, maka dapat menjadi alasan bagi pihak bank untuk menyatakan debitur tersebut melanggar isi perjanjian kredit.

Pasal 1320 KUH Perdata, telah menentukan bahwa apabila dalam suatu perjanjian (in concreto) telah terpenuhi keseimbangan dan keserasian, maka dapat tercapai pula kesepakatan yang sah antara para pihak. Apabila syarat ini tidak terpenuhi, maka Pasal 1338 KUH Perdata yang mengatur pengambilan keputusan dalam suatu perjanjian harus melibatkan kedua belah pihak seharusnya tidak dapat berlaku mutlak.44 Bargaining power yang seimbang antar para pihak merupakan suatu hal yang mutlak dalam suatu perjanjian, agar tidak ada pemaksaan kehendak oleh salah satu pihak yang merasa posisinya lebih kuat. Ketidakharmonisan isi perjanjian sebagaimana tercermin dalam klausul jaminan kredit bank pada PT. Bank Riau Kepri Cabang Tembilahan di atas tentu dapat dinilai melanggar asas keadilan.

Adanya perjanjian baku dalam praktik kehidupan masyarakat tidak boleh dibiarkan tumbuh secara liar. Sekali lagi penulis menegaskan bahwa praktik ini perlu ditertibkan melalui putusan pengadilan atas keberatan pihak debitur terhadap isi perjanjian kredit yang merugikan tersebut. Intervensi negara melalui pengadilan ini di tempuh dalam rangka memulihkan kembali rasa keadilan bagi para pihak. Selain itu negara juga sudah saatnya menetapkan peraturan perundang-undangan guna mengatur kriteria pelaksanaan asas kebebasan berkontrak, sehingga tidak berdampak pada ketidaksetaraan para pihak.

43 Situasi ini dapat saja terjadi pada debitur yang usahanya mengalami kemunduran, sementara perjanjian kredit sudah setengah jalan, tentu perlu mencari modal dengan harapan mampu menutupi utang angsuran kredit pada kreditur (bank). Biasanya debitur menggunakan jalan keluar dengan cara menjaminkan harta kekayaannya kepada kreditur lainnya, dalam rangka untuk mendapatkan modal usaha yang baru, sepanjang harta kekayaannya tersebut bukan merupakan bagian dari harta kekayaan yang sudah diikatkan dalam lembaga jaminan pada saat pengajuan kredit sebelumnya.

44 Sutan Remy Sjahdeini, Op. Cit., hlm. 185. 
Peraturan perundang-undangan perbankan yang ada belum menjamin perlindungan hukum bagi debitur yang posisinya lemah, maka kehadiran ketentuan peraturan perundang-undangan yang dapat menjamin kesetaraan para pihak dalam suatu perjanjian menjadi penting. Sebagai alternatif usulan, yaitu peraturan perundang-undangan tentang perjanjian kredit yang materi muatannya untuk mencegah ketidakadilan bagi para pihak, serta menyediakan mekanisme hukum apabila ada pihak yang dirugikan.

Asas keseimbangan perlu dituangkan dalam materi muatan peraturan tersebut sebagai dasar kekuatan berlakunya perjanjian kredit. Asas keseimbangan harus menjadi asas fundamental (pokok) hukum perjanjian, selain asas asas kesepakatan, asas kebebasan berkontrak dan asas pact sunt servanda. Selain itu juga penting mengakomodasi kriteria keseimbangan, yang mencakup tidak boleh ada dominasi salah satu pihak dalam menentukan isi perjanjian, adanya harmonisasi isi perjanjian dan tidak melanggar asas keadilan.

\section{Penutup}

Berdasarkan analisis di atas, dapat disimpulkan bahwa keadilan komutatif merupakan keadilan kebersamaan yang tidak memandang derajat dan kedudukan dalam masyarakat. Keadilan komutatif merupakan tujuan yang harus diwujudkan dalam hukum perjanjian. Penelitian ini menyimpulkan ada 3 (tiga) kriteria keseimbangan dalam perjanjian kredit bank untuk mewujudkan keadilan komutatif, pertama, tidak adanya pihak yang mendominasi; kedua, adanya harmonisasi isi perjanjian (prestasi) dan ketiga, tidak melanggar asas keadilan.

Mengenai kriteria pertama, mengandung maksud tidak boleh ada dominasi dalam menentukan isi perjanjian (prestasi). Kriteria kedua, yaitu harmonisasi isi perjanjian (prestasi), mengandung maksud bahwa hak dan kewajiban para pihak sesuai dengan beban pelaksanaannya dan tidak boleh saling bertentangan, sehingga harus didasarkan atas kehendak bersama sebagaimana terkandung dalam asas kesepakatan. Sementara untuk kriteria ketiga, mengenai tidak boleh melanggar asas keadilan ini dikarenakan keadilan (keadilan komutatif) merupakan asas yang harus diwujudkan dalam setiap perjanjian. Pelanggaran terhadap kriteria tersebut, seharusnya dapat menjadi dasar atau alasan menurut hukum bagi 
pengadilan untuk membatalkan perjanjian dengan maksud agar dapat memulihkan rasa keadilan para pihak.

Penulis mengajukan saran agar para pihak yang hendak membuat perjanjian, khususnya perjanjian kredit bank antara debitur dan kreditur, untuk memenuhi ketiga kriteria keseimbangan sebagaimana penulis maksud dalam penelitian ini. Pemenuhan kriteria tersebut dimaksudkan agar tidak ada pihak yang dirugikan dan tetap memeroleh keadilan atas suatu perjanjian yang dibuatnya. Selain itu, penulis juga merekomendasikan agar negara melalui lembaga yang berwenang menyusun regulasi yang dapat menjamin kesetaraan para pihak dalam suatu perjanjian. Negara juga harus mengakomodasi upaya hukum bagi pihak yang dirugikan, apabila terdapat suatu perjanjian (kredit bank) mengandung klausulklausul yang tidak memenuhi kriteria keseimbangan. Dengan merealisasikan gagasan ini, penulis optimis bahwa keadilan dalam perjanjian yaitu keadilan komutatif atau keadilan kebersamaan dapat berangsur-angsur terwujud.

\section{Daftar Pustaka}

\section{Buku}

Agustina, Rosa, Hukum Perikatan (Law Of Obligations), Pustaka Larasan, Bali, 2012. Ali, Achmad Menguak Teori Hukum (Legal Theory) dan Teori Peradilan (Judicialprudence) Termasuk Interpretasi Undang-Undang (Legisprudence), Cetakan kedua, Kencana Prenada Media, 2009.

Assegaf, AhmadFikri, Penjelasan Klausula Baku, PSHK, Jakarta, 2014.

Bruggink, J.J.H. alih bahasa Sidharta, B. Arief Rechts Reflecties (Refleksi Tentang Hukum), Citra Aditya Bankti, Bandung, 1999.

Budiono, Herlien, Asas Keseimbangan Bagi Hukum Oerjanjian Indonesia : Hukum Perjanjian Berdasarkan Asas-Asas Wigati Indonesia, Citra Aditya Bakti, Bandung, 2006.

Dale, Van,Groot Woordenboek der Nederlandse Taal, tiende drunk, Utrecht/Antwerpen, 1982.

Hernoko,AgusYudha,Hukum Perjanjian : Asas Proporsionalitas Dalam Kontrak Komersial, Kencana, Jakarta, 2010.

Kansil, C.S.T dan Christine S.T. Kansil, Pengantar Ilmu Hukum Indonesia, Rineka Cipta, Jakarta, 2011.

Kusumohamidjojo, Budiono,Panduan Untuk Merancang Kontrak, Grasindo, Jakarta, 2001. 
Mertukusumo, Sudikno,Mengenal Hukum: Suatu Pengantar, Cetakan Kedua, Liberty, Yogyakarta, 2005.

Miru, Ahmadi dan Sutarman Yudo, Hukum Perlindungan Konsumen, Raja Grafindo Persada, Jakarta, 2007.

Nieuwenhuis,J.H, Drie beginselen van contractenrecht, diss, 1979, RUL 1979 Deventer, 1979.

ND, Mukti Fajar. dan Yulianto Achmad, Dualisme Penelitian Hukum : Normatif dan Empiris, Pustaka Pelajar, Yogyakarta, 2010.

Rato, Dominikus, Filsafat Hukum: Mencari, Menemukan, dan Memahami Hukum, LaksBang Justitia, Surabaya, 2010.

Ridwan, M, dkk, Kamus Ilmiah Populer, Pustaka Indonesia, Jakarta, 2006.

Sidabalok, Janus, Hukum Perlindungan Konsumen di Indonesia, Citra Aditya Bakti, Bandung, 2006.

Simanjuntak, Ricardo, Teknik Perancangan Kontrak Bisnis, Kontan Publishing, Jakarta, 2011.

Sjahdeini, Sutan Remy, Kebebasan Berkontrak Dan Perlindungan Yang Seimbang Bagi Para Pihak Dalam Perjanjian Kredit Bank Di Indonesia, Institut Bankir Indonesia, Jakarta, 1993.

Soemitro,Ronny Hanitijo, Metodologi Penelitian Hukum dan Jurimetri, Ghalia Indonesia, Jakarta, 1990.

Sudarsono, Pengantar Ilmu Hukum, Rineka Cipta, Jakarta, 2007.

Tim Naskah Akademis BPHN, Naskah Akademis Lokakarya Hukum Perikatan, Badan Pembinaan Hukum Nasional, Jakarta, 1985.

Tim Penyusun, Naskah Akademik Hukum Kontrak, BPHN Kementrian Hukum dan HAM RI, Jakarta, 2013.

Ujan, Andre Ata, Keadilan dan Demokrasi (Telaah Filsafat Politik John Rawl, Kanisius, Yogyakarta, 1999.

\section{Peraturan Perundangan-Undangan}

Kitab Undang-Undang Hukum Perdata (Burgerlijk Wetboek)

Undang-Undang Republik Indonesia Nomor 10 Tahun 1998 tentang Perubahan Atas Undang-undang Nomor 7 Tahun 1992 tentang Perbankan (Tambahan Lembaran Negara Republik Indonesia Nomor 3790)

\section{Putusan Pengadilan}

Putusan Mahkamah Agung RI No. 3956 K/Pdt/2000 Perihal Putusan Kasasi Gugatan Perbuatan Melawan Hukum pencantuman klausul Penetapan dan Penghitungan Bunga Bank dilakukan oleh Bank. 
Putusan Pengadilan Tinggi Sby No. 628/Pdt/1999/PT.SBY, Perihal Putusan banding Gugatan Perbuatan Melawan Hukum pencantuman klausul Penetapan dan Penghitungan Bunga Bank dilakukan oleh Bank.

Putusan Pengadilan Negeri GS No. 37/Pdt.G/1998/PN. GS. Perihal Putusan Pengadilan Tingkat Pertama Gugatan Perbuatan Melawan Hukum pencantuman klausul Penetapan dan Penghitungan Bunga Bank dilakukan oleh Bank.

\section{Jurnal}

Arvie Johan, Kesetaraan dan Keseimbangan Sebagai Perwujudan Itikad Baik /Berlandaskan Pancasila, Jurnal Ilmu Hukum, Vol. 14, No. 1, 2011.

Baginda AJN, Ery Agus Priyono dan Dewi Hendrawati, Penerapan Asas Keseimbangan Sebagai Indikator Asas Kebebasan Berkontrak Dalam Perjanjian Pemborongan Upgrading Gudang LPG Di TBBM Semarang Group Antara PT Citra Agung Mandiri Utama Dengan PT Pertamina (Persero), Diponegoro Law Journal, Vol. 5, Nomor 4, 2016.

Etty Mulyaty, Asas Keseimbangan Pada Perjanjian Kredit Perbankan Dengan Nasabah Pelaku Usaha Kecil, Jurnal Bina Mulia Hukum, Vol. 1, No. 1, September 2016.

Jonneri Bukit, Made Warka dan Krisnadi Nasution, Eksistensi Asas Keseimbangan Pada Kontrak Konsumen Di Indonesia, Jurnal Ilmu Hukum, Vol. 14, No. 28 Agustus 2018.

Niru Anita Sinaga dan Tiberius Zaluchu, Peranan Asas Keseimbangan Dalam Mewujudkan Tujuan Perjanjian,Jurnal Ilmiah Hukum Dirgantara-Fakultas Hukum Universitas Dirgantara Marsekal Suryadarma, Vol. 8 No.1, September 2017.

R.M. Panggabean, Keabsahan Perjanjian Baku dengan Klausul Baku, Jurnal Hukum No. 4 Vol. 1, 2010. 